\title{
Internet Web Communication Technology (WCT) and Information Communication Technology (ICT) Development and Use for Veterinary Medicine Education in Nigeria (2000 -2009)
}

\author{
BABALOBI, 0.0 .
}

Department of Veterinary Public Health and Preventive Medicine, Faculty of Veterinary Medicine, University of Ibadan, NIGERIA. Corresponding address: E-mail:tayobabalobi@yahoo.com; 00.babalobi@mail.ui.edu.ng University Post Office Box 4150, Postal Code: 200005. Mobile Telephone: +234-805-530-1991. Website: http://www.ui.edu.ng/babalobi.htm

\section{SUMMARY}

Internet web communication technology (WCT) usage in Nigeria has increased tremendously over the last decade. Veterinary education and practices in Nigeria have also profited largely from advances in internet WCT mainly, in last two decade. Veterinary Medicine Electronic Journals such as Access to Global Online Research in Agriculture (AGORA), African Journal Online (AJOL), and Health Information Network Access to Research Initiative (HINARI) are available free online. In particular, the nvmaemailgroup@yahoogroups.com (the official email group of the Nigerian Veterinary Medical Association NVMA), the interactive electronic mail communication network for members of the Nigerian Veterinary Medical Association (NVMA), has greatly stimulated Nigerian Veterinarians worldwide to active utilization of Internet WCT. The phenomenal increase in internet usage in education is attributable to massive collaborative support by such funding body as the MacArthur Foundation, working along other partners in the project "Partnership for Higher Education in Africa (PHEA)". Contrarily, the level of ICT use in Nigerian education system, including veterinary medicine education, is still very low, with an estimated $90 \%$ of Nigeria's educational institutions still at the emerging/infancy stage due to low funding, paucity of ICT infrastructure, irregular and low quality power supply and high cost of ownership of ICT facilities including the capital and operational costs. There is a pertinent need to focus research into and actively promote the usage of ICT in enhancing research and education in developing countries, with collaborative funding by International Organizations.

Key words: Internet, Information Communication Technology, Veterinary Medicine, Nigeria

\section{Introduction}

The Internet Web Communication Technology (WCT) is a network of computer networks through which data, images, voice, and video are sent and received through both wireless and fixed-wire devices. The most known components of the Internet are the World Wide Web shortened to www, the Electronic mail (email), and Instant Messaging Services such as Yahoo Messenger ${ }^{\circledR}$, and $\mathrm{MSN}^{\circledR}$. The internet (WCT) is arguably one of the most significant technological developments of the late 20th century. Initially conceived in the seventies to act as a nuclear attack resistant method for exchange of scientific information, the internet was deployed for linking research agencies and universities. To date, a number of websites are dedicated to veterinary medicine research and education resources (Babalobi, 2005).

Information Communication Technology (ICT) is the processing and maintenance of information, and the use of all forms of computer, communication, network and mobile technologies to mediate information. Communication technologies include all media employed in transmitting audio, video, data or multimedia such as cable, satellite, fibre optics, wireless (radio, infra-red, Bluetooth, and Wifi). Network technologies include personal area networks (PAN), campus area network (CAN), intranets, extranets, local area networks (LANs), wide area networks (WANs), metropolitan area network (MANs) and the internet. Computer 
technologies include all removable media such as optical discs, disks, flash memories, video books, multimedia projectors, interactive electronic boards,

and continuously emerging state-of-the-art PCs. Mobile technologies comprises mobile phones, personal digital assistants (PDAs), palmtops, etc. These technologies have information as their material object. Information is not reserved for use in isolation, but, rather communicated among users. ICT applied to education enhances the delivery and access to knowledge and can tremendously improves the curriculum. It produces richer learning outcomes compared to education without ICT. It encourages critical thinking and offers unlimited means of achieving educational goals (Iloanusi and Osuagwu 2009).

Promoting and implementing the active use of WCT and ICT technologies in the professions (including veterinary medicine) in Africa, with the active collaboration and assistance of our Western WCT/ICT colleagues have been advocated in the past (Babalobi 2005).This paper seeks to highlight the trend of Internet and ICT usage over the last decade and draw attention to future priority areas in the ICT/WCT usage in enhancing research and education in developing countries by International Organizations.

\section{Internet Usage Trend in Nigeria's Tertiary Institutions (2000 -2009)}

There has been a tremendous improvement in internet WCT usage/ penetration in Nigeria particularly over the last five years. By June 2009, Nigeria has become the second highest user of the Internet in Africa after Egypt (Figure I), and Internet usage has increased from $0.1 \%$ in 2000 to $3.1 \%$ in 2006 and $7.4 \%$ in 2009 (Table I).

TABLE I: Internet Usage and Population Growth in Nigeria 2000 - 2009:

\begin{tabular}{|llllc|}
\hline YEAR & Users & Population & $\%$ Pen. & Usage Source \\
\hline 2000 & 200,000 & $142,895,600$ & $0.1 \%$ & ITU \\
2006 & $5,000,000$ & $159,404,137$ & $3.1 \%$ & ITU \\
2009 & $11,000,000$ & $149,229,090$ & $7.4 \%$ & ITU \\
\hline
\end{tabular}

Source: http://www.Internet World StatsINigeria Internet Usage, Population, and Telecommunications Market

Also remarkable is the growth of Internet WCT in Nigeria's tertiary institutions (though still comparatively low when related with other western tertiary institutions). An example is the University of Ibadan (U.I.), the country's oldest university and generally recognized as the premier institution of higher learning, which serves at least 27,000 students currently in 13 different academic disciplines (made up of 11academic faculties, the postgraduate school and the distant learning centre). University of Ibadan has moved from having only 25 dial-up links to the Internet in 2000 to a campus-wide system of 1,000 networked computers using wired and wireless technologies by 2005 (http://www.macfound.org/enewsletters September 28, 2005). The university's local area network has grown from the 2004 figure of 15 LAN-unit to over 65 units in 2007 and 75 units in 2009, with 11 Faculties linked by fibre cable ICT Network Operating Centre (NOC). The total number of computers systems on the network grew from about 650 in 2004 (Babalobi, 2005), to over 2,250 at the end of 2007 and about 4,000 in 2009 (Raji, Director MIS/ICT, University of Ibadan, Personal Communications, 2010). Bandwidth similarly increased from 512/2048 kbps up/ down to $1536 / 7352 \mathrm{kbps}$ up/down for the VSAT at main campus and from $256 / 1024$ to $740 / 3072$ for the VSAR at the College of Medicine (Source: UI and MacArthur (2007): Partnership that helps Ibadan spread wings: The University of Ibadan Story) The University's operations gradually 
moved online with the development of the University's portal (http// www.portal.ui.edu.ng)in 2007. Over $70 \%$ of the critical activities of the University moved online by the end of 2007 and $80 \%$ by the 2009; and all admissions (undergraduate and postgraduate) became fully operational online. The University's website (http://www.edu.ng) was redesigned to be more robust and user-friendly in content and management systems (Source: UI and MacArthur (2007): Partnership that helps Ibadan spread wings: The University of Ibadan Story 2007). By the end of 2009, the whole campus (academic area) had wireless coverage (Raji, Director MIS/ICT, University of Ibadan, Personal Communications, 2010).

In addition, under the Library Strengthening Programme, a Computer Laboratory has been provided at the Kenneth Dike Central Library to provide students and other users of the library access to the Internet. The Laboratory also incorporate a multimedia room where students can package information related to their study and research fields. The library is redesigned to accommodate 100 personal computers, including laptop bays and serve as an in-house facility for university staff training, The Library currently subscribes to a number of electronic journals and is being automated so that it can be accessed electronically (Source: UI and MacArthur (2007): Partnership that helps Ibadan spread wings: The University of Ibadan Story).

Perhaps the most important factor in this remarkable growth has been collaborative funding involving a number of international organizations. The phenomenal increase in internet usage in Education is attributable to massive collaborative support by such funding bodies as the MacArthur Foundation, working along other partners in the "Partnership for Higher Education in Africa" (PHEA) (http://www.foundationpartnership.org/index.php?id=9), a joint project of Carnegie Corporation of New York, The Ford Foundation, the John D. and Catherine T. MacArthur Foundation, the
Rockefeller Foundation, the William and Flora Hewlett Foundation, the Andrew W. Mellon Foundation and the Kresge Foundation. Established in 2000, PHEA represents both a belief in the importance and viability of higher education in Africa and a mechanism to provide meaningful assistance to its renaissance. Between 2000 and 2005, the foundations invested more than $\$ 150$ million in 40 universities in six nations serving a combined enrolment of about 300,000 students (http://www.macfound.org/enewsletters, September 28, 2005).

The University of Ibadan has particularly benefitted from the MacArthur Foundation for its remarkable growth in Internet use. Beginning from 2002, the JOHN D and CATHERINE T MACARTHUR FOUNDATION has awarded three 3-year grant, amounting to a total of US\$10,400,000 (over one billion Nigerian Naira), to the University towards institutional strengthening, repositioning and renewal as well as community outreach in seven specific areas: this led to the phenomenal rise in internet use and access at the University (Source: UI and MacArthur: Partnership that helps Ibadan spread wings. The University of Ibadan Story, 2007).

Figure 1.

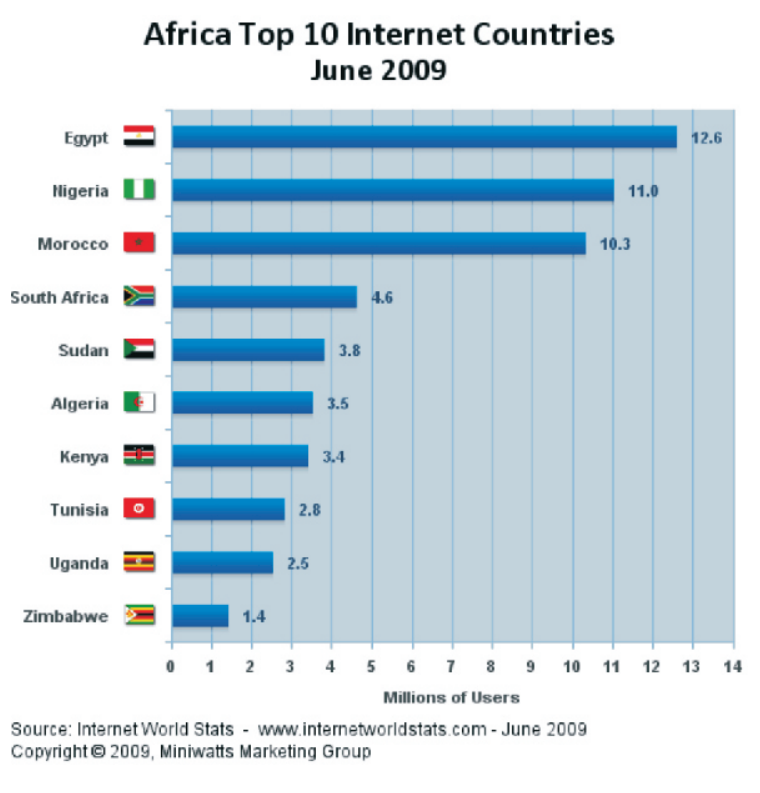




\section{ICT Usage Trend in Nigeria's Tertiary Institutions (2000 -2009)}

Various authors have written on the use of ICT in Nigeria's Tertiary Institutions (http://www.foundation partnership.org/pubs/ict/index.php; World Bank, 2003; Oyelakin, 2008; Iloanusi and Osuagwu, 2009). The consensus was that the level of ICT use in Nigerian Education system is still very low. According to Iloanusi and Osuagwu $(2009$,$) investments in ICT in Nigerian$ education have not yielded reasonable expectations compared to similar investments made in the Global System for Mobile communication (GSM). In educational institutions, especially institutions of higher learning, the mode of delivery of knowledge and curriculum are not yet ICT-enhanced. It is obvious that ICT is still in the emerging/infancy phase in Nigerian educational system and hurdles remain in the infusion of ICT in educational institutions. These hurdles include low funding, paucity of ICT infrastructure, irregular and low quality power supply and high cost of ownership of ICT facilities which include capital and operational costs (Iloanusi and Osuagwu 2009). Aniebonam (2007) has proposed "Designing a Workable ICT Intervention" under a Nigerian Tertiary Institutions Ict Intervention Projects, under a Federal Government Education initiative with private sector involvement and community participation. The above situation in ICT development and use in Nigeria's Higher Educational System is despite the fact that Partnership for Higher Education in Africa PHEA, facilitated the phenomenal internet WCT usage in Nigerian tertiary over the last decade, and also kicked-off a Workshop for African Universities titled "Securing The Linchpin: Ict For Teaching, Learning, And Research-a Workshop For African Universities" between 29 July-1 August 2002 at the United Nations' International Conference Centre, Addis Ababa, Ethiopia, in partnership with the United Nations Economic Commission for Africa. (http://www.foundationpartnership.org/pubs/ict/index.php). Following the Addis Ababa workshop, The Nigeria ICT Forum of Partnership
Institutions (NGICTFORUM) was formed as an initiative of Nigerian Research \& Higher Education Institutions Registered in Nigeria as a not-for-profit Company Limited by Guarantee (RC 632001) on 19 August 2005. NGICTFORUM is an initiative of the Nigerian Caucus (a joint meeting of the ViceChancellors and ICT Coordinators of the six Partnership Nigerian Universities) held in Dar-er-Salaam on 9 September 2004, with the stimulation and support of the MacArthur Foundation and the Carnegie Corporation. Its goals were to;

i. develop ICT-based capacity for strengthening Research and Higher Education Institutions (HEIs);

ii. facilitate and nurture collaboration between HEIs to cultivate a favourable policy environment;

iii. develop, utilise and sustain ICT networks, services and shared resources consistent with institutional roles as foci for development (http://forum.org.ng)

Part of the mandate of the Nigeria ICT Forum (http://forum.org.ng/) is to serve as a vessel to drive the formation of a Nigerian National Research and Educational Institution Network (NREN) from the 95member Association of Vice-Chancellors of Nigerian Universities (AVCNU) and the Committee of Vice-Chancellors and the 100member Council of Heads of Polytechnics and Colleges of Technologies in Nigeria (COHEADS) (Update on setting up of the Nigerian NREN: Key Issues 2009).

\section{ICT/ Internet Wet Usage In Veterinary Medicine Education}

One of the most comprehensive recent articles on the application of ICT to veterinary medicine was written by Simões, (2010). According to him, Veterinary education has profited largely from information communication technology (ICT) advances, mainly, in the last two decades. The ICT advances gives new opportunities and challenges for biological scientists and teachers, veterinarians, veterinary technicians, practice managers, veterinary students and veterinary technician students. Other than their effects 
on laboratory and clinical diagnosis of diseases in domestic, exotic and wild animals or hospital organizational models, ICTs are also responsible for new paradigm in animal production, food animal safety, public health and environment protection, and improved geospatial information technologies. The ICTs were progressively applied in research and teaching in veterinary schools mainly in the developed countries.

According to Simões, (2010), in the last two decades, an improvement of electronic and digital devices use for veterinary medical and animal production purposes associated to the networks and computation development were observed in veterinary field. Many students, veterinarian and related professionals adopt digital devices for data storage, computation and communication to date. The use of internet for educational and professional purposes also enhanced their interrelationships with society. The classic use of ancillary digital devices, connected to computers, personal digital assistants and servers for teaching and learning purposes in public and private analytical laboratories and veterinary hospitals was changed to a more active interaction with intra and internet systems.

An important aspect of internet WCTs use is the literature accessibility for publication purpose. Simões, (2010) has also traced developments in this area from the last decade (1990s) when hard books or journals, diskettes, Compact Disc Read Only Memory

(CD-ROM) and DVD-ROMs (Digital Video Discs) were the main vehicles for technical and scientific information, preserving copyrights and royalties. These developments include:

i. The National Library of Medicine (NLM) of US began the online public domain

Visible Human Project ${ }^{\circledR}$ (http://www.nlm.nih.gov/research/visible/visi ble_human.html) in order to create three-dimensional representations of the normal male and female human bodies in 1986. Today, the NLM in collaboration with the National Institutes of Health (NIH; http://www.nih.gov) and National Resource for Molecular Biology Information (NCBI) play, also, an important role for free online biomedical information database search, like the PubMed services (http://www.nih.gov/about/index.html). This database includes over 18 million citations from Medical Literature Analysis and Retrieval System Online (MEDLINE the largest component of PubMed) and other bioscience articles back to 1948.

ii. From 1993 to 1996, the Computer-aided Learning in Veterinary Education (CLIVE), a consortium of six United Kingdom (UK) veterinary schools and 14 international Associate Member Schools was funded by the UK Higher Education Funding Councils' Teaching and Learning Technology Programme. This consortium makes ComputerAssisted Learning (CAL) packages, e.g. biomedical veterinary and templates \& multimedia contents, for veterinary undergraduate and postgraduate education, in all subjects of the veterinary curriculum (http://www.clive.ed.ac.uk).

iii. The Bioline International (http://www.bioline.org.br), a not-for-profit electronic publishing was launched in 1993 by Brazil and UK (now in association with the University of Toronto) and was pioneer in open access to peer-reviewed bioscience journals of developing countries in the world. BI's goal of reducing the South to North knowledge gap is crucial to a global understanding of health (tropical medicine, infectious diseases, epidemiology, emerging new diseases), biodiversity, the environment, conservation and international development. By providing a platform for the distribution of peer-reviewed journals (currently from Bangladesh, Brazil, Chile, China, Colombia, Egypt, Ghana, India, Iran, Kenya, Malaysia, 
Nigeria, Tanzania, Turkey, Uganda and Venezuela), BI helps to reduce the global knowledge divide by making bioscience information generated in these countries available to the international research community world-wide. Nigeria, Brazil and Iran are the most active countries.

iv. The World Wide Web (WWW) Virtual Library Veterinary Medicine, a selected collection of veterinary medical internet resources. NetVet Website (http://netvet.wustl.edu/vet.htm) was launched in 1994, as an experimental free veterinary Web service to collect veterinary medicine and animal welfare resources. It is a US based gateway to internet sites on animal health, veterinary practices, animal safety and tips on buying pets. It is maintained by Ken Boschert, DVM, based at the Division of Comparative Medicine, Washington State University.

v. CABI (http://www.cabi.org), a Sciencebased but non-profit organization, for agricultural development, animal production and health fields in British Commonwealth. Now, they also develop several animal production and health fields with digital resources from 1970s.

vi. The Health InterNetwork Access to Research Initiative (HINARI), which was launched in 2002 with 1500 journals from 6 major publishers (Blackwell, Elsevier Science, the Harcourt Worldwide STM Group, Wolters Kluwer International Health \& Science, Springer Verlag and John Wiley). According to HINARI site (http://www.who.int/hinari/), in 2009, more than 6200 journal titles were available for health institutions in 108 countries.

vii The Access to Global Online Research in Agriculture project (AGORA) was launched in 2003, like HINARI, but in the food, agriculture and environmental sciences fields. By 2009, 1278 journals in institutions of 107 countries were provided by AGORA (http://www.aginternetwork.org/)

viii.In 2006, the public-private consortium Online Access to Research in the Environment (OARE) was created. The main aim was to improve the quality and effectiveness of environmental science research, education and training, also in developing countries and is coordinated by United Nations Environment Programme (UNEP), Yale University and science and technology publishers of several fields (ht t p:// www.oaresciences.org) ix. For more specific African and Asian continents, other scholar and scientific online libraries were developed. The African Journals OnLine (AJOL) "provides free hosting for over 340 peer-reviewed journals from 25 African countries. These journals cover the full range of academic disciplines with strong sections on health, education, agriculture, science and technology, the environment, and arts and culture" (http://www.ajol.info/)

ix This project was initiated in 1998 by the International Network for the Availability of Scientific Publication (INASP). After two re-launches (2000 and 2004), it was moved to South Africa, in 2005, as a non-profit-company. In 2004, INASP (http://-www.inasp.info) was registered as UK charity after they creation, in 1992, by the International Council for Science (ICSU; http://www.icsu.org/index.php. They are present in Asian, African and also American developing countries with the objective to stimulate the local development as communication, knowledge and networks fields.

x. Thomas Reuters Web of Knowledge (http://wokinfo.com/). Fifty years after birth (1960), the Institute for Scientific Information (ISI), now called the Thomas Reuters Web of Knowledge, is the more important commercial online scientific and academic database platform. The content and tools 
Thomson Reuters Web of Knowledge delivers is what sets this research resource apart from any other. That's why over 20 million researchers from over 4,700 institutions in 98 countries base their research, planning, and budget decisions on the content and analytics they find in Web of Knowledge. (http://wokinfo.com/about/facts/).Thi $\mathrm{s}$ is due in part to academic recognition of their scientific journals evaluation. This database service covers all scientific fields and is funded, after 2008, by the Thomson Reuters enterprise (http://www.thomsonreuters.com). The Web of Science, ISI Proceeding, Biological Biosis, Biosis, Previews and Zoological Record (Biosis) are the mains databases incorporating biological, agricultural, and animal and human health fields hosted in the ISI Web of Knowledge. The access to full charged articles is, in part, provided by commercial libraries like ScienceDirect (http://www.sciencedirect.com/; Elsevier, The Netherlands).

xi. I n t e rne t Vet ( ht t p : / / www.vts.rdn.ac.uk/tutorial/vet/), written and maintained by Laurian Williamson of BIOME, University of Nottingham and VetGate is a UK gateway to high quality Internet resources in Animal HealthVetGate is part of BIOME (http://biome.ac.uk) which is a collection of gateways providing free access to evaluated, quality Internet resources in the health and life sciences, aimed at students, researchers, academics and practitioners. BIOME is part of the Resource Discovery Network (http://www.rdn.ac.uk/).

xii. The Resnick Library@sunydelhi (http://www.delhi.edu/library) is another major Veterinary Science site on the Internet

xiii.Other free, private but not strictly veterinary scholarly and scientific search engines include the Google Scholar (http://scholar.google.com/) and Scirus (http://www.scirus.com/ NR).

\section{ICT Usage In Veterinary Medical Education In Nigeria}

The earlier proponents on the promotion of ICT in Veterinary Education in Nigeria include Babalobi 2003, 2005 and 2006; Babalobi et al., 2002, 2004, 2005; Hassan, et al., 2004). In 2005, Computer-aided Learning In Veterinary Education < http://www.clive.ed.ac.uk/ > CLIVE, a UK based organization, sent a large selection of CD-ROMs following a request by the then President of the Uthman Dan Fodyio University Sokoto, Nigeria branch of International Veterinary Students Association (IVSA), requesting donations of interactive learning materials for the Veterinary Medical students' library. The CD-ROMs were gratefully received and now being used by the students to further their studies in Veterinary education.

At the University of Ibadan, Ibadan Nigeria, United States of America Foreign Animal Diseases CD-ROMs, supplied by the United States Department of Agriculture USDA, as well as Community Animal Health Scheme CD-ROMs supplied under the Pan African Control of Epizootics PACE of the InterAfrican Bureau for Animal Health of the African Union IBAR-AU, are regularly used as multimedia tool in clinical teaching of Veterinary Public Health and Preventive Medicine to undergraduate classes. Meanwhile additional WCT and ICT information is constantly been added to the course "Computer Application in Veterinary Practice", a final year DVM course at the University of Ibadan, Nigeria, while opportunity to benefit from CLIVE associate membership is still being sought (CLIVE Associate Membership Scheme $<$ http://www.clive.ed.ac.uk/about/associa te.htm $>$ ).

\section{Trend of Internet WET Usage in Veterinary Medicine, Nigeria}

The application of aspects of ICT/WCT to veterinary research and practice has recently been actively promoted in Nigeria (Babalobi et al 2002; Babalobi, 2003; 
Babalobi et al., 2004; Hassan et al., 2004; Babalobi and Cowen, 2001). Internet usage in Veterinary Medicine in Nigeria has particularly improved in the past decade with veterinarians subscribed to and contribute reports to a number of professional e-groups including: vph1@mailserv.fao.org,promed@promedmail.o rg, nigeriavetphpmforum@yahoo.com;

ANIMALNET-L@listserv.uoguelph.ca, e-vet@yahoogroups.com, ppgis@dgroups.org, epidemio-1@LISTES.UMontreal.CA, info@ivis.org, auvec@yahoogroups.com, http://ICTupdate.cta.int, http://www.worldvet.org, www.e-agriculture.org, (africanvetlib) Veterinary Librarians listserv and the nvmaemailgroup@yahoogroups.com (the official email group of the Nigerian Veterinary Medical Association NVMA)..

In particular, the nvmaemailgroup@yahoogroups.com (the official email group of the Nigerian Veterinary Medical Association NVMA) and the interactive electronic mail communica-tion network for members of the Nigerian Veterinary Medical Association (NVMA), has greatly stimulated Nigerian Veterinarians worldwide to active utilization of Internet WCT. Similarly, available online as http:// pets.groups.yahoo.com/group/nvmaemail group/, it was founded on $11^{\text {th }}$ November 2006 and has a membership of 1091 subscribers who had exchanged 4306 messages as at $16^{\text {th }}$ May 2010. The impact of the egroup on veterinary medicine in Nigeria has recently been acknowledged by the conferment of Excellent Performance Award, 2006 on the author by the NVMA, at $44^{\text {th }}$ NVMA National Congress Warri, Delta State Nigeria; as well as listing on the "Roll of Honour" site on the NVMA website (http://www.nvmang.org/roll_of_honour. htm)

Internet Usage Trend in Veterinary Medicine at The University of Ibadan, Nigeria

Within the University Community, the Faculty of Veterinary Medicine has benefitted significantly in all the earlier mentioned improved facilities, in particular access to online publications and journals needed for research and teaching purposes. In addition, six computers have been connected to the Internet at each of the Faculty and the Department of Veterinary Public Health and Preventive Medicine. . However, erratic power supply prevents the maximum utilization of these facilities. The maiden edition of KDL News, a bi-annual publication of the University of Ibadan Central library, the Kenneth Dike Library put the Faculty of Veterinary Medicine Library in perspective and highlighted the lists of Veterinary Medicine Electronic Journals available via:

- Access to Global Online Research in Agriculture AGORA (21 in all)

- African Journal Online AJOL (7 in all), and

- Health Information Network Access to Research Initiative HINARI (76 in all) (KDL News(2010). Who is a Librarian?)

\section{Conclusion}

The development and use of internet WCT in Nigeria, including its application to the education and practice of veterinary medicine has improved tremendously in the last decade. However, erratic power supply and the relative high cost of internet services still limit the utilization of internet service in all aspects of life, including veterinary practice, and training. Tackling these twain problems will enhance greater utilization and maximization of internet opportunities in Nigeria. On the other hand, the level of ICT use in the Nigerian education system, including veterinary medical education, is still very low. This is due to poor funding, paucity of ICT infrastructures, irregular/erratic power supply and high cost of ownership of ICT facilities (capital and operational costs). Simões, (2010) has stated that the elementary advances recorded in the use of ICT technologies in Veterinary Medicine will have to be closely related with the future ICT development in all fields in the global society. The future of ICTs and its role in enhancing research and education for maximum agricultural performance is a major issue that needs 
more funding, promotion and support by various international development agencies.

\section{References}

ANIEBONAM, M. C. (2007): Using Technology to Drive Educational Reforms Educational Reforms in Nigeria, 16/2007 CTO2007, Lagos Nigeria United States Commercial Service 3; 11 pp.

BABALOBI O. O. (2003): The Use of Egroups (List serve mailing lists) for the Development of the Veterinary Profession in Nigeria. Nigeria Veterinary Journal.Vol.24 (3), 179-185.

BABALOBI O. O. (2005): Professional Issues for the Nigerian Veterinarian in the twenty-first century. Nigeria Veterinary Journal. Vol. 26 (2). 1-7.

BABALOBI O.O. (2006): Towards a development and use of internet web and information communication technologies for veterinary medicine education in Nigeria. In VAN DER WESTHUIZEN, EE \& CROFT, V (Eds.), Running wild, running free: capturing, harnessing and disseminating knowledge flows in support of animal health: 5th International Conference of Animal Health Information Specialists, 4-7 July 2005, Onderstepoort, South Africa, University of Pretoria, Veterinary Science Library, Pretoria, South Africa, http://www.library.up.ac.za/vet/icahis . ISBN: 1868565482 . URI: http://hdl.handle.net/2263/6393. Rights: (CUniversity of Pretoria. Book chapter pp. 73-80.

BABALOBI O. O. and Cowen P. (2005) "PROMED - mail: An electronic mail disease-reporting forum". Nigeria Veterinary Journal. Vol. 25 (2). 63-67

BABALOBI, O.O, FABIYI, O. AND OGUAMANAM, L., (2002): Application of Geographical Information Systems to veterinary medicine: an overview. Tropical Veterinarian. 20 (2): 117125.

BABALOBI, O.O., OGUNDIPE, G.A.T, AND ONYEKA L. (2004) Towards an increasing awareness and use of Geographical Information Systems (GIS), Remote Sensing (RS) And Global
Positioning Systems (GPS) in veterinary medicine in Nigeria. 41st Annual Congress of the Nigerian Veterinary Medical Association. Vom, Jos, Nigeria. November 2004.

BABALOBI, O. O., ONYEKA, L. AND OGUNDIPE, G.A.T (2005): 'Towards an Increasing Awareness and Use of Veterinary Geo-Information Technologies in Nigeria: A Review.' Vom Journal of Veterinary Science. Vol. 1(2), $45-51$.

HASSAN, A.Z., MOHAMMED, I., REMIADEWUMI, B.D. AND UMAR, M.R (2004). Computer Application in Veterinary Medicine. Nigerian Veterinary Journal 25. (2)1-12.

http://biome.ac.uk. Accessed $17^{\text {th }}$ May 2010 http://forum.org.ng/. (Copyright (C) 20052010. The Nigeria ICT Forum of Partnership Institutions. 25 Libreville Street, Off Aminu Kano Crescent, Wuse II, Abuja. Tel: +234-9-8746732 email: info@forum.org.ng). Accessed 17 $7^{\text {th }}$ May 2010

http://netvet.wustl.edu/vet.htm. Accessed $17^{\text {th }}$ May 2010

http://wokinfo.com/. Accessed $17^{\text {th }}$ May 2010

http://wokinfo.com/about/facts/ Accessed $17^{\text {th }}$ May 2010

http://www.aginternetwork.org/. Accessed 17th May 2010

http://www.ajol.info/. Accessed 17th May 2010

http://www.bioline.org.br. Accessed $17^{\text {th }}$ May 2010

http://www.cabi.org/ . Accessed $17^{\text {th }}$ May 2010

http://www.clive.ed.ac.uk/. Accessed $17^{\text {th }}$ May 2010

http://www.clive.ed.ac.uk/about/associate .htm. Accessed $17^{\text {th }}$ May 2010

http://www.delhi.edu/library. Accessed $17^{\text {th }}$ May 2010

h t t p : / / w w w. f o u n d a t i o n partnership.org/index.php?id $=9$. Accessed $17^{\text {th }}$ May 2010

http://www.inasp.info. Accessed $17^{\text {th }}$ May 2010

http://www.macfound.org/enewsletters, September 28, 2005 
http://www.nih.gov/. Accessed 17th May 2010

http://www.nih.gov/about/index.html. Accessed 17th May 2010

http://www.nlm.nih.gov/research/visible/ visible_human.html. Accessed 17th May 2010

http://www.nvmang.org/roll_of_honour.ht m. Accessed 17th May 2010

http://www.oaresciences.org. Accessed 17th May 2010

http://www.rdn.ac.uk/. Accessed $17^{\text {th }}$ May 2010

http://www.thomsonreuters.com Accessed $17^{\text {th }}$ May 2010

http://www.vts.rdn.ac.uk/tutorial/vet/. Accessed $17^{\text {th }}$ May 2010

http://wokinfo.com/ Accessed 17 $7^{\text {th }}$ May 2010

http://www.who.int/hinari. Accessed 17th May 2010ICT for Teaching, Learning, and Research-A Workshop for African Universities 29 July-1 August 2002 United Nations, International Conference Centre Addis Ababa, Ethiopia Organized by the Partnership for Higher Education in Africa In Collaboration with the United Nations Economic Commission for Africa. h t t p : / / w w w. fou nd a tion partnership.org/linchpin/index.php; Accessed $17^{\text {th }}$ May 2010

ILOANUSI, N. O. AND OSUAGWU, C. C. (2009): ICT in Education: Achievements so far in Nigeria. In
Research, Reflections and Innovations in Integrating ICT in Education. Edited by A. Méndez-Vilas, A. Solano Martín, J.A. Mesa González and J. Mesa González. Published by FORMATEX, Badajoz, Spain. 1331-1335.

JOÃO SIMÕES (2010): Information communication technology applied to veterinary education in early XXI century, Veterinaria.com.pt 2010; Vol. 3 $\mathrm{N}^{\circ} \quad 1$ : e $1 . \quad 1-29$. http://www.veterinaria.com.pt/media/ /DIR_27001/VCP2-1-e1.pdf.

KDL News (2010). Who is a Librarian? A Biannual Publication of the Kenneth Dike Library, University of Ibadan, Nigeria. Vol. 1, No. 1 February 2010. 9 - 13.

OYELAKIN, O. S. (2008): An Overview of the Status of Information and Communication Technology (ICT). In Nigerian Educational System www.ncsu.edu/aern/TAS8.2/TAS8.2 Oyelekan.pdf [The African Symposium (ISSN TX 6-342-323) Vol. 8 No 2 2008). 8-14.

UI AND MACARTHUR: PARTNERSHIP THAT HELPS IBADAN SPREAD WINGS. THE UNIVERSITY OF IBADAN STORY. 2007. 104pp.

WORLD BANK (2003), ICT at a glance: Nigeria http://www.com. washington.edu/ict4d. 